\title{
PERFORMANCE IMPROVEMENTS OF TAX AND CUSTOMS AUTHORITIES. CASE STUDY: LATVIA
}

\author{
Mara Petersone ${ }^{1}$, Karlis Ketners ${ }^{2}$ \\ ${ }^{1}$ Department of Customs and Taxes, Faculty of Engineering Economics and Management, \\ Riga Technical University, Kalnciema 6, LV-1048 Riga, Latvia \\ ${ }^{2}$ Department of Finance, BA School of Business and Finance, K. Valdemara 161, LV-1013 Riga, Latvia \\ E-mails: ${ }^{1}$ mara.petersone@rtu.lv (corresponding author); ${ }^{2}$ karlis.ketners@ba.lv
}

\begin{abstract}
The aim of this paper is to investigate performance management of the State Revenue Service (SRS) of the Republic of Latvia in the context of effective public budgeting. This article investigates performance indicators in the context of process (activity) management in tax and customs authority and examines a number of practical issues with regard to the design of management practices. Several research methods, such as analysis of academic and professional publications and logical and comparative analysis, are applied in this research. The main findings are related to the analysis of activities of SRS and could be practically implemented at SRS.
\end{abstract}

Keywords: New public management, performance, public administration, performance indicators, process management, state revenue service.

JEL Classification: H83; H11.

\section{Introduction}

Any democratic country seeks to organize its State administration as effectively as possible, constantly checking and, if necessary, improving it. This means that State institutions form their administrative structure according to the functions and tasks defined in laws and regulations in order to achieve their objectives in cost-efficient and functional manner as well as to ensure good quality for services provided to the citizens. Drucker (1993), states that business enterprises and public-service institutions are organs of society which do not exist for their own sake but to fulfil a specific social purpose and to satisfy need of society, community, or individual.

Spekle and Verbeeten (2014) conclude that effectiveness of the introduction of performance measurement systems in the public sector organizations thus depends both on contractibility and on how the system is being used by managers. Ferry and Eckersley (2015) stresses that the top-down accountability in public administration is mostly focused on fiscal compliance rather than on organizational performance management, while the bottomup responsibility is much more transparent; however, it is not strictly standardised thus may lead to the weakening of accountability.

Although the performance of financial planning and performance management are considered as separate concepts, in practice, many governments are trying to introduce result-based approach to both management and financial planning context, where organisations are given some flexibility regarding the way how performance improvements are achieved (OECD 1997). Many countries tend to improve both financial planning and performance management of their tax and customs administrations thus harmonising their top-down and bottomup accountability. International experience as well as national practice in Latvia has approved that it is essential to harmonize public financial contribution with regard to the purpose it is spent on and the results to be achieved. In order to achieve joint policy and budgetary planning, gradual shift from the planning of expenditure lines to the result-based budget at both national level and at the level of individual institutions is justified.

As Alm and Duncan (2014) indicates, further, even if the agencies are inefficient, tax administrators have limited control over such variables as a country's tax capacity, its tax laws, and the willingness of taxpayers to participate in the formal versus the informal sector. Agencies can influence internal agency allocations and processes and there are also likely to be some other environmental factors that affect tax collections over which tax administrators have some control. To improve revenue performance, policymakers therefore need to focus both on the relative efficiency of tax agencies and also on those factors that affect efficiency over which administrators have some control. 
For the State Revenue Service as a part of public administration two concepts of efficiency are also important. As described by Robinson (2007), the first of these is technical efficiency, which corresponds to the public administration concept and refers to the choice of the least cost combination of inputs for the production of the good or service concerned, for given input prices. Some aspects of this efficiency evaluation were described by Lace and Filipovica (2007). The other relevant economic concept is allocative efficiency - production of the best or optimal combination of outputs given society's valuation of those outputs. Allocative efficiency requires technical efficiency and is tended to maximize social well-being (utility from public services). The degree of allocative efficiency of government expenditures depends not only on the effectiveness of government expenditures in achieving their intended outcomes but also on considerations if these outcomes are beneficial to society as well as changes in utilities by changing the output mix.

With 4040 employees in 2014 the State Revenue Service is one of the largest direct State administration authorities in Latvia. The State Revenue Service performs customs and tax administration functions in Latvia, which comprises more than $78 \%$ of the general budget of the State for tax and non-tax revenue. The State Revenue Service is a specific public authority as it plays an important role not only in administering revenues of the State but also in ensuring sustainable national development and maintaining secure international supply chain system. Like other direct State administration authorities, the SRS (State Revenue Service) has to achieve its objectives by using the allocated budget in a cost-efficient manner. Budget management of the State Revenue Service should comply with the common changes introduced to the State budget management. The question about adequate funding for the State Revenue Service remains open with regard to the performance of its functions and adequacy of financing with regard to the achieved results including the budget implementation. By planning the maintenance expenditures in the SRS budget, rational and efficient use of available resources is intended, while also assessing the functions of public authority, tasks and deliverables of employees as well as the necessary number of employees and their qualifications (The Rules of Preparation on budgetary requests 2012). Although laws and regulations stipulate the procedures of expenditure justification for institution, for the moment the instruments available for activating this mechanism are not used.
Budget management model of the State Revenue Service is oriented towards the identification of expenditure item (type). This budget management model and the institution's operational performance are not mutually linked; therefore interaction between the public investment (budgetary funds, human resources, as well as logistical support) and the quality and quantity of the services provided by the institution is not ensured as a result.

The article purpose is to link outcomes to operating process concerns and manage implementation problems related to conflicting initiatives in individual government agencies.

This article objectives are to investigate performance indicators in the context of process (activity) management in tax and customs authority and examines a number of practical issues in the design of management practices.

Several research methods, such as the analysis of academic and professional publications, and logical and comparative analysis, are applied in this research.In the paper an empirical illustration based on case study in the Latvian SRS is provided. The research results relate to the guidelines for SRS performance management and budget expenditure relationship. The main findings related to the analysis of activities of SRS and could be practically implemented at SRS.

\section{Cash flow planning practice}

A result-oriented budgeting system is characterized by management approach, which includes performance evaluation. Applying this budget planning technique the main management object is policy programme objectives (package of several activities aimed at achieving the objectives set by the government), as well as qualitative and quantitative performance indicators. The result-oriented budgets are gradually replacing traditional budgeting methods. The system of result-oriented budgets in Latvia exists formally but in reality the budget planning is not associated with the policy objectives and deliverables, making a major emphasis on the detailed lineitem planning and control. The main difficulties associated with this model are complex assessment of whether output is an appropriate tool and way for achieving the results of desired policy outcome in the best possible way (Klavina et al. 2003). In addition, society wants the resources allocated to the State institutions for representing public interests to be minimal, services - of a good quality, and most importantly - it should be done in transparent manner. These are three main factors that determine the nature of management inevery State institution. 
Figure 1 shows the total resources for SRS expenditures and the proportion of SRS expenditures in the revenue of general State budget with its development over last 14 years.

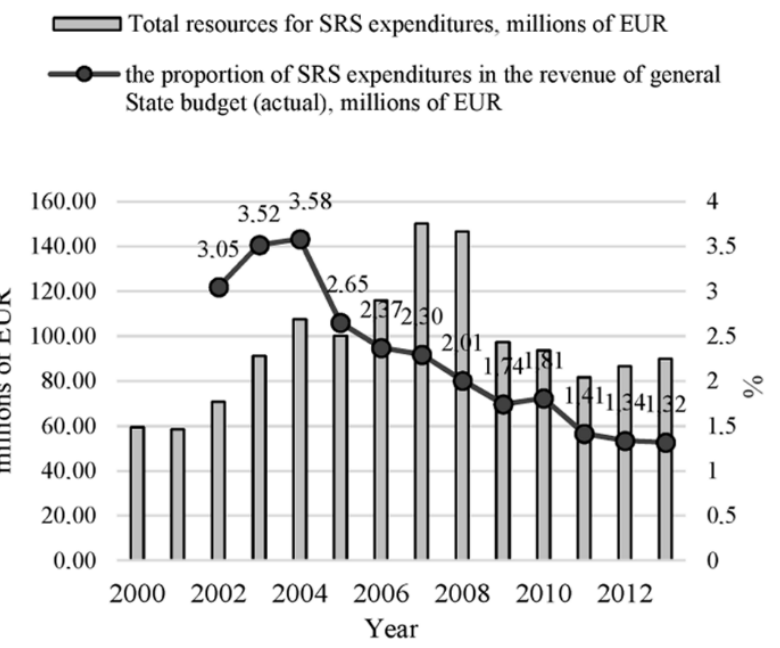

Fig. 1. Total resources for SRS expenditures and the proportion of SRS expenditures in the revenue of general State budget (actual), millions of EUR and \%

(Source: Annual budgetary laws from 2000 to 2014, SRS the annual reports from 2000 to 2014 , the statistics on activities from 2000 to 2014, Annual reports of State

Treasury, ministries and central State institutions)

Information included in Figure 1 shows that the proportion of SRS expenditures in relation to the state general budget has decreased from $3.05 \%$ in 2002 to $1.32 \%$ in 2013 that results in changes of $57.4 \%$. In assessing the SRS expenditures in absolute figures, it could be stated that the total resources for SRS expenditures over the period from 2000 to 2013 has increased by $151.6 \%$. Over the period under consideration, the greatest amount of financial resources was allocated to the SRS in 2007, namely, it has increased by $252.96 \%$ comparing 2007 to 2000; however, the total resources for SRS expenditures decreased by $59.92 \%$ in 2013 reaching the same levels as in 2003.

Figure 2 shows total expenditure of the tax administration as a percentage of revenue collected among OECD member countries and candidate countries having similar institutional division of customs and tax authorities as Latvia.

As shown in Figure 2, Latvia has the fourth highest total expenditure level of the tax administration as a percentage of revenue collected among the compared countries. There is also no regularity between size of customs and tax administration and total expenditure of the tax administration as a percentage of revenue collected.

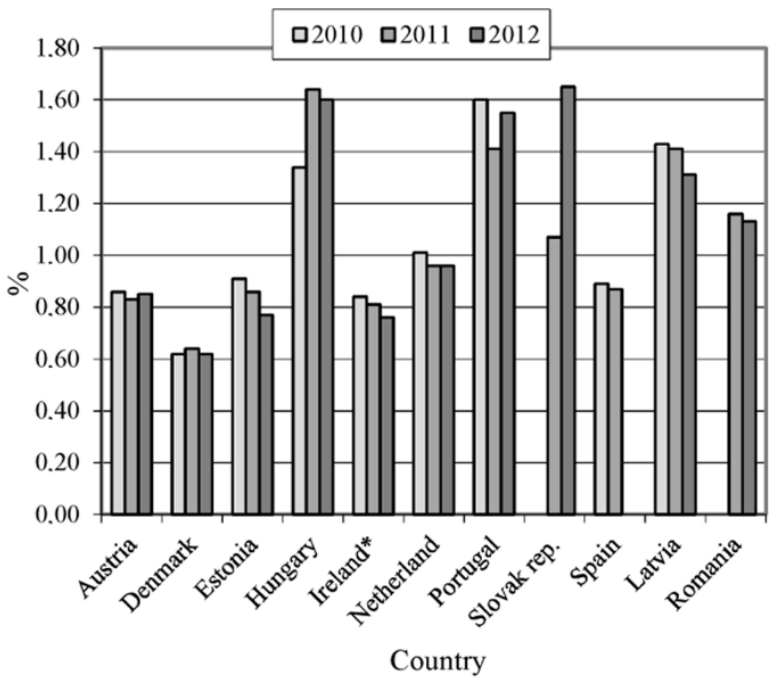

Fig. 2. Total expenditure of the tax administration as a percentage of revenue collected (\%) (Source: IOTA 2015)

Notes: Calculated based on the following formula $=$ (Administrative costs + Employment costs + IT expenditure + other costs $) \times 100 /$ Total revenue.

Revenue is an integrated tax and customs administration. The total expenditure as a $\%$ of revenue collected is based on total gross receipts for all taxes, duties, levies and monies collected on behalf of other government departments or agencies. No account is taken of imputed costs, such as pensions and accommodation rental, which are not borne by revenue.

Figure 3 presents an analysis how an intangible investment, namely, personnel, is related to the development of the implementation of SRS administered revenue plan. The SRS personnel capacity is indirectly linked to the expenditure changes of the

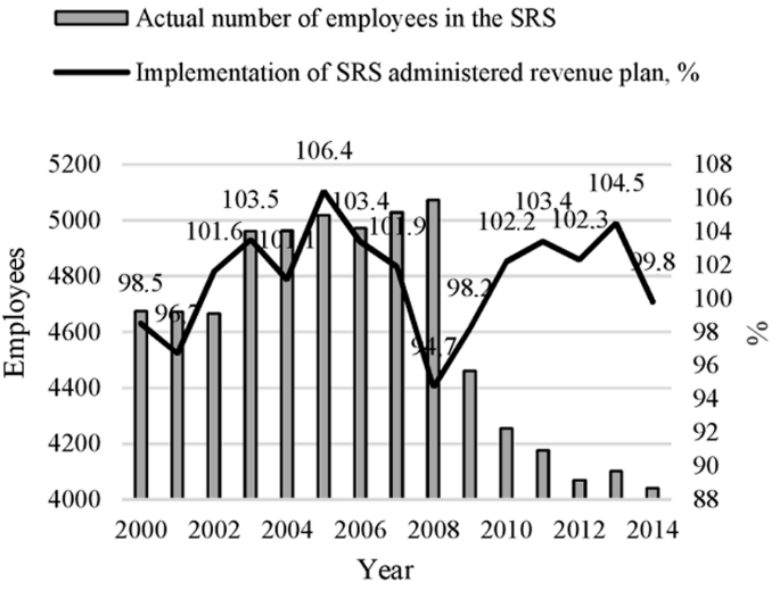

Fig. 3. Actual number of employees in the SRS on the last day of respective year and implementation of SRS administered revenue plan, \% (Source: SRS unpublished statistics from 2000 to 2014) 
institution as salaries obviously constitute significant part of the administrative expenses $(61.2 \%$ in 2013). Large number of employees alone does not serve as proof for successful implementation of budget revenue plan. Figure 3 shows the actual number of employees in the SRS on the last day of respective year.

Figure 3 shows that in 2014 the SRS had the lowest level of employees with 4040 position, which is $20 \%$ less compared to 2008 , when the implementation of SRS administered revenue plan was the lowest and $0,7 \%$ less compared to 2013 , when the implementation of SRS administered revenue plan was one of the highest. Assessing the implementation of revenue plan (percentage) and the quantitative composition of the SRS employees leads to the following conclusions / observations:

- In 2010, 2011, 2012 and 2013 SRS ensured implementation of budget revenue plan (above $100 \%$ ) with very limited personnel resources, which diminished rapidly;

- After 2006, reaction of the SRS by adjustments in personnel capacity (personnel reduction) in accordance with the changes in tax implementation plan was belated by 2 years; this observation can be also linked to the slow SRS reorganization process;

- The number of the SRS employees in 2014 was in the same level as in 2013 (less than 4102 employees). From the perspective of SRS administered revenue plan implementation, it is feasible by maintaining the lowest number of employees in the last 10 years in the same time.

A significant reduction in government spending in 2009 and strict fiscal discipline measures introduced by the Ministry of Finance have created conditions, when regular critical review of the SRS logistic support as well as human resources capacity was necessary. In this period the reduction of available budget prompted to start significant optimization of functions and reorganization of units, which has been done. Sometimes, beginning reorganization of the SRS, there was a lack of true understanding about the effect to be achieved by the structural reforms, thus reorganization becomes an end in itself, not a prerequisite and tool for achieving objectives of the institution. Consequently, neither the institution improves its overall performance, nor increases its operational effectiveness; therefore the related expenditures are unnecessary wasted money. For example, after numerous structural changes, the SRS has not examined, whether the desired objectives are achieved or if the structural changes affect tasks and processes of the SRS, resulting in wasted resources on structural reforms.

The government of Latvia has successfully improved availability of the performance indicator information with regard to the budget management information by approving the basic principles of performance measures (The Guidelines on Outcomes and Performance System for the Period of 2008-2013). These basic principles are aimed at developing the system of result performance measures, namely, they tend to not only improve policy planning but also improve the informative quality of indicators and their practical application of budgetary planning, implementing and monitoring process. The widely shared and applied practices are implemented in these principles to ensure adequate substantive quality of performance measures. The principles include the requirement for ministries to adapt their operational strategies to the structure of programmes by linking their objectives to each programme and sub-programme, applying the planned and actual performance measures as well (Rules on the Basic Principles of a budgetary Request Preparation and Submission 2012).

Practice on the inclusion of the information in the budget of OECD and other countries varies. Some of the countries reduce information to be included in the budget performance indicators limiting it to the summary of indicators for the sake of transparency. However, this may cause unnecessary simplification and incorrect incentives. Despite of this, if performance indicator information is / is not included in the budget documentation, it is important to collect it, to inform legislator about it and make it publicly available, thus creating awareness for any discussion on programme performance and spending efficiency.

With regard to the new performance management, the tax and customs administrations gradually adopt the best practices from other countries and follow recommendations of the European Commission (2007). The performance management documents, such as the Business Plan, Annual report, Service delivery standards and Surveys of taxpayers, have been adopted as best practice and are used in almost all of the countries concerned with slight variations in the fact if these documents are publicly available (see Table 1).

The authors have considered selected management practices of revenue body of the EU Member States, such as Austria, Denmark, Estonia, Greece, Hungary, Ireland, the Netherlands, Portugal, the Slovak Republic, Spain, Romania and Latvia, which are the OECD (Organization for Economic Co-operation 
Table 1. Selected management practices: business plans, annual reports, surveys (Source: OECD 2015)

\begin{tabular}{|c|c|c|c|c|c|c|c|c|c|}
\hline \multirow[b]{3}{*}{ Country } & \multicolumn{9}{|c|}{ Selected management practices of revenue body } \\
\hline & \multicolumn{2}{|c|}{$\begin{array}{l}\text { Business } \\
\text { plan }\end{array}$} & \multicolumn{2}{|c|}{$\begin{array}{l}\text { Annual } \\
\text { report }\end{array}$} & \multicolumn{3}{|c|}{$\begin{array}{l}\text { Service } \\
\text { delivery } \\
\text { standards }\end{array}$} & \multicolumn{2}{|c|}{$\begin{array}{l}\text { Surveys } \\
\text { of } \\
\text { taxpayers }\end{array}$} \\
\hline & 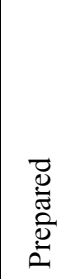 & $\begin{array}{l}\frac{0}{\frac{0}{0}} \\
\frac{0}{0} \\
\frac{0}{0} \\
\frac{\pi}{\Sigma}\end{array}$ & 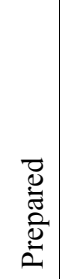 & $\begin{array}{l}\stackrel{0}{0} \\
\frac{0}{0} \\
\frac{0}{0} \\
\frac{\tilde{J}}{2} \\
\Sigma\end{array}$ & $\overrightarrow{\tilde{\omega}}$ & $\begin{array}{l}: 0 \\
\frac{0}{0} \\
0 \\
0 \\
\frac{0}{0} \\
\sum\end{array}$ & 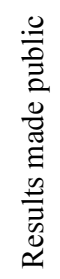 & 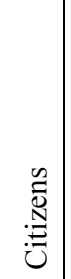 & 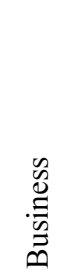 \\
\hline Austria & $\sqrt{ }$ & $\mathrm{X}$ & $\sqrt{ }$ & $\sqrt{ }$ & $\sqrt{ }$ & $\sqrt{ }$ & $\sqrt{ }$ & $\sqrt{ }$ & $\sqrt{ }$ \\
\hline Denmark & $\sqrt{ }$ & $\sqrt{ }$ & $\sqrt{ }$ & $\sqrt{ }$ & $\mathrm{X}$ & $\mathrm{X}$ & $\mathrm{X}$ & $\sqrt{ }$ & $\sqrt{ }$ \\
\hline Estonia & $\mathrm{X}$ & $\mathrm{X}$ & $\sqrt{ } / 1$ & $\sqrt{ } / 1$ & $\sqrt{ }$ & $\sqrt{ }$ & $\sqrt{ }$ & $\sqrt{ }$ & $\sqrt{ }$ \\
\hline Greece & $\sqrt{ }$ & $\sqrt{ }$ & $\sqrt{ }$ & $\sqrt{ }$ & $\sqrt{ }$ & $\mathrm{X}$ & $\sqrt{ }$ & $\mathrm{X}$ & $\mathrm{X}$ \\
\hline Hungary & $\sqrt{ }$ & $\sqrt{ }$ & $\sqrt{ }$ & $\sqrt{ }$ & $\sqrt{ }$ & $\sqrt{ }$ & $\sqrt{ }$ & $\mathrm{X}$ & $\mathrm{X}$ \\
\hline Ireland & $\sqrt{ }$ & $\sqrt{ }$ & $\sqrt{ }$ & $\sqrt{ }$ & $\sqrt{ }$ & $\sqrt{ }$ & $\sqrt{ }$ & $\sqrt{ }$ & $\sqrt{ }$ \\
\hline Netherland & $\sqrt{ }$ & $\mathrm{X} / 1$ & $\sqrt{ }$ & $\sqrt{ } / 2$ & $\sqrt{ }$ & $\sqrt{/ 2}$ & $\sqrt{ } / 2$ & $\sqrt{ }$ & $\sqrt{ }$ \\
\hline Portugal & $\sqrt{ }$ & $\sqrt{ }$ & $\sqrt{ }$ & $\sqrt{ }$ & $\sqrt{ }$ & $\sqrt{ }$ & $\mathrm{X}$ & $\sqrt{ }$ & $\sqrt{ }$ \\
\hline Slovak rep. & $\sqrt{ }$ & $\sqrt{ }$ & $\sqrt{ }$ & $\sqrt{ }$ & $\sqrt{ }$ & $\sqrt{ }$ & $\sqrt{ }$ & $\mathrm{X}$ & $\mathrm{X}$ \\
\hline Spain & $\sqrt{ }$ & $\sqrt{ }$ & $\sqrt{ }$ & $\sqrt{ }$ & $\sqrt{ }$ & $\sqrt{ }$ & $\sqrt{ }$ & $\sqrt{ } / 1$ & $\sqrt{ }$ \\
\hline Latvia & $\sqrt{ }$ & $\sqrt{ }$ & $\sqrt{ }$ & $\sqrt{ }$ & $\sqrt{ }$ & $\sqrt{ }$ & $X$ & $\sqrt{ }$ & $\sqrt{ }$ \\
\hline Romania & $\sqrt{ }$ & $\sqrt{ }$ & $\sqrt{ }$ & $\sqrt{ }$ & $\sqrt{ }$ & $\sqrt{ }$ & $\sqrt{ }$ & $\sqrt{ }$ & $\sqrt{ }$ \\
\hline
\end{tabular}

and Development) countries or candidate countries having integrated their tax and customs administrations into one organization (OECD 2015).

In Latvia, the SRS prepares its operational strategy as performance management document, which is publicly available only since 2011 . Institutions include information on the implementation results of operational strategies in their annual public reports. The SRS customer service standards have been developed in Latvia and are publicly available since October 2014. It is interesting that the customs administration, intending to ensure easy, fast and standardized customs clearance processes of goods, has set the time standards in order to ensure quality and effectiveness of customs clearance activities undertaken by the State Revenue Service National Customs Board control points in order to ensure quality and efficiency of the delegated tasks, which can also be regarded as customer service standards. Unfortunately, the deliverables of customer service standards are not published in Latvia. Opinion of the tax payers (both natural and legal persons) on the provision of services is asked every two years, for example, in customer service quality survey in customs (Latvian Facts 2012). State institutions submit information on the State budget programme deliverables to the Ministry of Finance every year.

Government settings are that different levels of deliverables and performance indicators should be aligned both horizontally and vertically. Therefore it is not important, if we talk about political or operational (strategic, tactical, operational and individual level) set of the performance indicators but it is important that the deliverables and their performance indicators are designed to provide the report on the planned and achieved results to the relevant stakeholder group, which is involved in the formulation of indicators, thus achieving a certain degree of agreement on key deliverables and their performance indicators. However, it must be taken into account that the Latvian legislation regulates only the planning process of the public administration with regard to macro impact, political and operational results in the strategic level. Usage specifics of the economic efficiency indicator groups depend on individual institutions, and, consequently, coordination of the strategic and tactical, operational and individual level indicators remain in the competence of each institution. However, these three levels of performance indicators are the most important in order to ensure support for expenditure of the State institutions and link them to the performance.

\section{Integrated performance and financial system in the SRS}

The State administration planning system hierarchy in Latvia is determined by the regulatory acts cascading down objectives and ensuring their traceability from the highest planning documents down to the plans at institutional level, thereby creating confidence that the institution includes the objectives, which are set in the State long-term plans, in its medium-term strategic plans, thus ensuring that the common long-term objectives of the State are achieved through daily activities of institutions. One of the preconditions for ensuring traceability for long-term planning is the horizontal link among planning documents of different periods. Cascading of objectives and their traceability is equally important from the medium-term documents down to the plans of individual employees, thereby creating confidence that the institution ensures achieving its short-term objectives in its strategic plans, which are medium-term documents, through individual everyday activities of employees. Unfortunately, in practice cascading of objectives and their traceability from the highest level planning documents of the State down to the plans of individual employees is rather formal and is not methodologically justified and based on scientific arguments. Development planning documents include objectives and results to be achieved in the respective policy sectors, identify problems and provide solutions, evaluate the 
potential impacts of these solutions, as well as plan further measures, which are necessary for policy implementation and result assessment, but above all they link development planning with financial planning, which in practice represents the major challenge.

Authors believe that the SRS financial planning system as well as human resources management system of the organization, which are based on process management system, are capable of ensuring all of the institution's management aspects successfully (see Fig. 4). With regard to the existing instrument - process control system, top-down approach is to be used for performance management context, while the bottom-up approach is to be used for planning of expenditure items, where each management level has its instruments available is the case of the SRS.

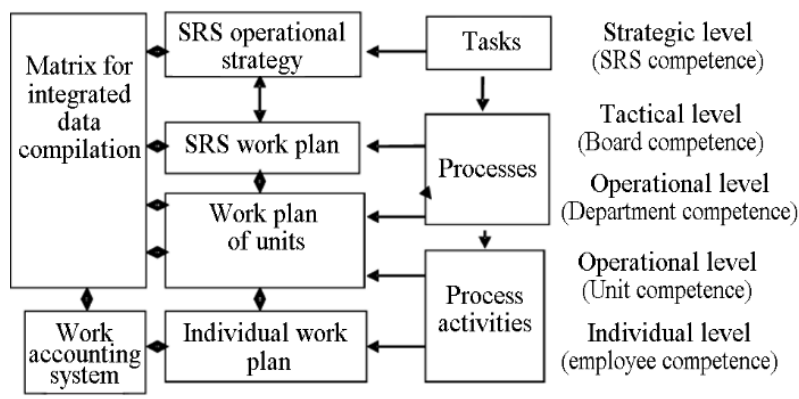

Fig. 4. Integrated performance planning system SRS (Source: author's construction)

The SRS has divided its activities into three levels - task, process and operational process level, where every task can be regarded as downstream processes (reflected in the Rules of procedure of every board and department), while every process is defined in the process steps (reflected in Rules of procedure of every unit and work description of every position) (see Fig. 4). As a result, each structural unit has its processes and process activities (Petersone 2013). Process management system includes deliverable of every process. In this way, by using appropriate tools, work load of each structural unit and all institution can be measured. Each employee's work description consists of his/her work responsibilities in the post of civil servant reflecting operational processes in his/her competence, which is considered to be list of work duties (Petersone et al. 2014). With the instrument called "Working time accounting system" each employee's work within a fixed period can be calculated and compared to the individual work plan. As a result, actual deviations from the individual work plan can be assessed. In the case of small deviations within the limits of corrections, changes are necessary by adding or removing processes (work duties) to equalize the workload.

The SRS has recently established work result compilation matrix, where information about the work results of the SRS structural units is collected, which cannot be considered as performance indicators to measure strategy performance. The SRS work result compilation matrix is like instrument, which can be used parallel to the performance indicators for summarizing the work results of the SRS structural units with no clear link with other levels of performance indicators (Petersone et al. 2015). By integrating the performance indicators of the tactical and operational levels into the result matrix and indicating the management level these deliverables correspond to, as well as their potential impact on the strategic level, a pool would be created. Ensuring the result traceability in all levels of performance and linking them in this way would be helpful for managing the performance process of the SRS. Namely, linking all levels of performance indicators it is possible to establish hierarchy of indicators and to relate them to the strategic objectives. Performance indicators of each operational level should be compared with the plans of appropriate level. This comparison of operational, tactical and managerial levels is essential not only with regard to performance indicators but to analytical indicators as well, because these can be used for finding an answer to the question if operation of the respective structural units and organizations is efficient. An integrated compilation of the results matrix, which is offered by authors, can be used as a universal source of information rather than simple SRS results matrix with 1028 performance indicators (On the State Revenue Service's Performance Outcome), which is currently used by the SRS. The analytical indicators group of current performance measurement system seems to be strongly focused on showing organizational performance to the society.

By linking the Working time accounting system to the matrix of integrated result compilation it is possible to create an information base not only on quantitative indicators but also on time consumption for the processes and calculate actual costs. The matrix of integrated result, which is linked to the Working time accounting system, provides all necessary information for the bottom-up financial planning. Information regarding changes in the number of positions within a structural unit and organization can be obtained directly from this integrated performance management system. Unfortunately, system deficiencies as well as technical problems were detected in the SRS Working time accounting system, which should be used to calculate the working time 
according to guidelines, and it was decided to cancel the respective guidelines.

Linking such matrix of the indicators would bring closer performance and financial planning (see Fig. 5).

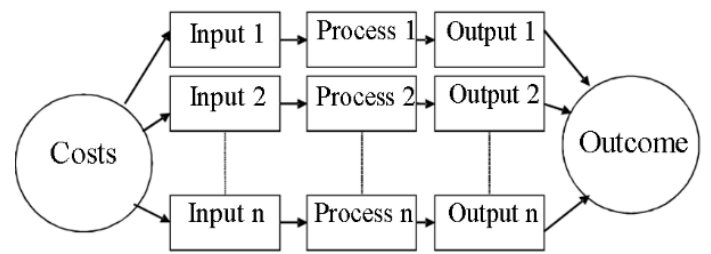

Fig. 5. Integrated performance and financial planning approach in the SRS (Source: author's construction)

By its nature, the plans of structural units (operational level of units and departments) reflect the sum of work performed by the employees of the respective structural unit. In the operational level (department competence), it is possible to identify the costs of the process and sum them up to obtain the total costs (see Fig. 5). The process results in output, namely, deliverables of departments, boards and all organization. On the other hand, outcome indicates, whether the measures taken have led to the political result.

Performance management system is not only directly linked to human resource management but it is a part of this system. The authors suggest an idea of integrated human resource management, which requires coordinated use of all management systems and which is based on process approach. Consequently, process management system is an instrument, which is helpful for arranging and improving every area of management. These have been traditionally been risk and / or quality management. Nakrošis and Černiūte (2010) argue that more mature institutions, which have experience in applying other innovative performance management techniques, are also likely to apply quality management initiatives. SRS has implemented risk management system, which is based on process management (Petersone 2014). Performance management system in the SRS has been built using process approach. Latvia and Lithuania is gradually adapting the New Public Management ideas in the human resources management in the public sector. This is largely consistent with the Lithuanian new recruitment model of civil service, which was developed from the ideas of the New Public Management (Tumenè et al. 2014). The authors agree with Rekašienè and Sudnickas (2014) that the perspective of various possibilities of the competency model application in different human resources management areas is presented. Rimkute et al.
(2014) approves the idea of authors about the integrated human resources management as in the framework of performance management concept in Lithuania there is also discussion about changes in strategic planning, the systems of financial and human resources and the outcomes of the institutional framework conversion.

\section{Conclusions}

Tax and customs administrations in several countries tend to improve financial planning performance of performance and performance management, using coordination of top-down and bottomup responsibility. Budget management model that focuses on the identification of expenditure items (type), is not mutually linked with the institution's operational performance, as a result interaction between the public investment (budgetary resources, human resources, as well as logistical support) and the quality and amount of services provided by the institution is not ensured. In order to achieve a common policy and budgetary planning, it is reasonable to gradually shift from the expenditure item planning to the result budget at both State level and level of every institution.

Experience has shown that the current performance indicators used by the SRS have to be significantly improved, so that they could be used for budget management in practice. Performance indicators should be compared with the plans of appropriate level at every level of activities. Such comparison in operational, tactical and managerial levels is essential not only with regard to the performance indicators but also to the analytical indicators as these, above all, may provide an answer, if the relevant structural unit and organization in general works efficiently. An integrated compilation of the results matrix, which includes a group of analytical indicators, can be used as a universal source of information rather than simple SRS results matrix, which is currently used by the SRS.

In order to improve the State Revenue Service budget management model, which ensure adequate budget management flexibility and dynamic coherence with the institution's operational objectives and deliverables, top-down approach should be used in to performance management, while the bottomup approach - in the planning of expenditure items. In the case of such dual approach both performance management and financial planning are applicable process management systems.

By linking the Working time accounting system to the matrix of integrated result compilation it is possible to create an information base not only on 
quantitative indicators, but also on time consumption for the processes and calculate actual costs. Integrated results matrix, which is linked to the Working time accounting system, provides all necessary information for the bottom-up financial planning.

Performance management system not only is directly linked to the human resource management but it is a part of this system, consequently, the integrated human resource management approach requires coordinated functioning of all management systems, including financial management.

\section{References}

Alm, J.; Duncan, D. 2014. Estimating tax agency efficiency, Public Budgeting \& Finance 34(3): 92-110. http://dx.doi.org/10.1111/pbaf.12043

Annual budgetary laws from 2000 to 2014 and their explanatory memorandums, and the statistics on activities (the SRS administered budget revenue performance) from 2000 to 2014 published on the SRS home page [online], [cited 15 May 2015]. Available from Internet: https://www.vid.gov.lv/default. aspx?tabid $=11 \& \mathrm{id}=7338 \& \mathrm{hl}=1 \&$ IIzveleId=7122

Annual reports of state treasury, ministries and central state institutions [online], [cited 15 May 2015]. Available from Internet:

http://www.kase.gov.lv/l/ministriju-un-centralovalsts-iestazu-parskati/152

Drucker, P. F.1993. Management: tasks, responsibilities, practices. New York: Harper \& Row Publishers.

European Commission - Taxation and Customs Union. 2007. Fiscal field, select A path to a robust, outside and efficient tax administration. Office for Official Publications of the European Communities, Luxembourg. ISBN 978-92-79-05369-6.

Ferry, L.; Eckersley, P. 2015. Budgeting and governing for deficit reduction in the UK public sector: the ACT three 'accountability and audit arrangements', Public Money and Management 35: 203-210. http://dx.doi.org/10.1080/09540962.2015.1027496

IOTA. 2015 [online], [15 November 2015]. Available from Internet: http://www.iota-tax.org/

Klavina, S.; Petersone, B.; Klapkalne, U.; Sturis, V.; Jankovskis, J.; Sics, U. 2003. Budget reforms. State budget planning and development tendencies English and in the world. State Chancellery, Riga.

Lace, N.; Filipovica, N. 2007. X-inefficiency of the tax administration, in $14^{\text {th }}$ International Scientific Conference ,Enterprise Management: Diagnisis, Strategy, Efficiency”, 5-6 October 2006, Vilnius, Lithuania. Vilnius: Technika, 89-92.

Latvian Facts. 2012. Research [online], [cited 15 May 2015]. Available from Internet: https://www.vid. gov.lv/default.aspx?tabid $=4 \& \mathrm{id}=73 \& \mathrm{hl}=1$
Nakrošis, V.; Černiūtè, R. 2010. Quality management in the Lithuanian public administration: main initiatives and their application, Public Policy and Administration 31(1): 63-76. eISSN 2029-2872/ ISSN 1648-2603.

OECD. 1997. In search of results. Performance measurement practices. OECD, PUMA, Paris. ISBN 92-6415574-0.

OECD. 2015. Tax administration, 2013: comparative information on the OECD and other advanced and emerging economies. OECD Publishing. http://dx.doi.org/10.1787/tax_admin-2015-en

On the State Revenue Service's Performance Outcome. 2014. State Revenue Service order No. 480. 14 March 2014.

Petersone, M. 2013. Features of process management in customs, in XIV International Scientific Conference "Create Future: Communication, Education, Business", 30-31 May 2013, Business School Turiba Ltd., Riga, Latvia, 209-220. ISSN: 1691-6069

Petersone, M. 2014. Practical measures for integrity promotion at the Latvian customs, in Proceedings of the Interdisciplinary Scientific International Conference for PhD Students and Assistants (2014 QUAERE), 26-30 May 2014, Magnanimitas, Hradec Králové, Czech Republic, 530-539. ISBN 97880-87952-04-7.

Petersone, M.; Ketners, K.; Krastins, A. 2014. Advances in Latvian customs education - lessons learned, International Journal of Education and Information Technologies 8: 18-27. ISSN 2074-1316.

Petersone, M.; Ketners, K.; Krastins, A. V. 2015. Development of system of state revenue service performance indicators, in $16^{\text {th }}$ International Conference "Economics Science for Rural Development": Finance and Taxes, 23-24 April 2015, LLU, Jelgava, Latvia, 190-200. ISBN 978-9984-48-180-7.

Rekašienè, R.; Sudnickas, T. 2014. Competency models development and application prospects in Lithuanian civil service, Public Policy and Administration 13(4): 590-600. http://dx.doi.org/10.13165/VPA-14-13-4-04

Rimkutè, E.; Kirstukaitè, I.; Šiugždinienè, J. 2014. Public sector performance management in Lithuania: progress and challenges implementing results-based management, Public Policy and Administration 13(1): 9-24.

Robinson, M. 2007. Performance budgeting: linking funding and results. International Monetary Fund, Washington, DC. http://dx.doi.org/10.1057/9781137001528

Rules on the Basic Principles of a Budgetary Request Preparation and Submission. 2012. Approved by the Cabinet of Ministers Order No. 523 of July 31, 2012 [online], [cited 25 August 2015]. Available from Internet: http://likumi.lv/doc.php?id=250610 
Spekle, R. F.; Verbeeten, F. H. M. 2014. The use of performance measurement systems in the public sector: effects on performance, Management Accounting Research 25: 131-146.

http://dx.doi.org/10.1016/j.mar.2013.07.004

SRS the annual reports from 2000 to 2014. [Online], [cited 16 October 2015] Available from Internet: https://www.vid.gov.lv/default.aspx?tabid=4\&id= $8 \& \mathrm{hl}=1$

SRS unpublished statistics from 2000 to 2014 The Guidelines on Outcomes and Performance System for the Period of 2008-2013. Approved by the Cabinet of Ministers Order No. 344 of June 18, 2008 [online], [cited 06 September 2015]. Available from Internet: http://likumi.lv/doc.php?id=177116
The Rules of Preparation on budgetary requests. 2012. Approved by the Cabinet of Ministers Order No. 523 of 31 July 2012 [online], [cited 24 October 2015]. Available from Internet: http://likumi.lv/doc.php?id=250610

The statistics on activities from 2000 to 2014 (the SRS administered budget revenue performance) published on the SRS home page [online], [cited 27 July 2015]. Available from Internet: https://www.vid.gov.lv/default.aspx?tabid=11\&id $=7338 \& \mathrm{hl}=1 \&$ lIzveleId $=7122$

Tumène, R.; Žukauskaite, I.; Židonis, Ž. 2014. The new system of civil service selection: first results and insights, Public Policy and Administration 13(4): 601-617.

http://dx.doi.org/10.13165/VPA-14-13-4-05 